\title{
DANDY-WALKER VARIANT (DWV) IN 70 YEARS OLD WOMAN WITH DISEQUILIBRIUM AND CENTRAL VERTIGO : A CASE REPORT
}

\author{
Ria Damayanti ${ }^{1}$, Muhammad Welly Dafif ${ }^{1}$, Shahdevi Nandar Kurniawan ${ }^{1}$, Badrul Munir $^{1}$, Zamroni Afif $^{1}$ \\ ${ }^{I}$ Neurology Department, Medical Faculty, Brawijaya University, Saiful Anwar General Hospital, Malang, Indonesia. \\ Correspondence :dr.riadamayanti@gmail.com
}

\begin{abstract}
Dandy Walker Syndrome (DWS) and its Variants (DWV) is a congenital disorder that has prevalence of 1 in 25,000 to 30,000 births with the highest incidence occurs at age $<1$ year. However, patients may be diagnosed with DWS/DWV for the first time in adolescence and even old age. We reported the 70-year-old woman with a chief complaint of central type vertigo accompanied by disequilbrium. From history taking we obtained disequilibrium with gradual onset started in nine months and become settled since the last 6 months before she came to the neurology clinic. The patient also complained vertigo that have emerged since the last 3 month. A history of head trauma, stroke, dementia was denied. Physical examinaton show central nystagmus while other cranial nerve within normal range. Motor, sensory and autonomic status within normal range. Romberg test, tandem walking, disdiadokokinesia, and dismetria examination shows abnormal respons. MMSE results for patients within normal range (score:26). Head MRI shows Dandy Walker Variant in the accompanied by cerebral atrophy and degeneration serebelli Fazekas grade I. Patients receive symptomatic therapy betahistine mesylate $3 \times 6 \mathrm{mg}$ if necessary. Surgery management is not indicated because there is no sign of hydrocephalus or signs of increased intracranial pressure.
\end{abstract}

Keyword : Dandy Walker Syndrome, vertigo, disequilibrium

\section{PENDAHULUAN}

Dandy Walker Syndrome (DWS) atau disebut juga malformasi Dandy Walker merupakan kelainan kongenital yang memiliki karakteristik adanya hipoplasi vermis serebelum, dilatasi kistik ventrikel ke empat, dan pembesaran fossa posterior, baik disertai ataupun tanpa disertai hidrosefalus (1,2). Dandy Walker Variant (DWV) merupakan istilah yang digunakan pertama kali oleh Harwood-Nash dan Fitz, untuk menggambarkan kondisi kelainan DWS yang lebih ringan dan tidak sepenuhnya sesuai dengan gambaran klasik DWS. Kelainan DWV termasuk diantaranya adalah adanya defek pada vermis inferior serebelum dan adanya hubungan antara ventrikel IV dengan sisterna magna yang berukuran normal. Selain kedua jenis tersebut, juga dikenal istilah Dandy Walker Compleks (DWC) untuk menggambarkan kelainan fossa posterior yang di kelompokan menjadi mild (hanya terdapat mega sisterna magna saja), moderate (jika terdapat hipoplasia ringan vermis serebelum, pembesaran ventrikel IV), dan severe (jika terjadi agenesis vermis, dilatasi fossa posterior dan dilatasi ventrikel IV) (1).
Dandy Walker Syndrome pertamakali dideskripsikan secara klinis berdasarkan hasil autopsi pada tahun 1887 oleh Sutton. Pada tahun 1914, Dandy dan Blackfan menyadari keterkaitan antara hidrosefalus dan dilatasi kistik ventrikel IV pada seorang bayi wanita berusia 13 bulan. Karakteristik abnormalitas tersebut di gambarkan oleh Dandy pada tahun 1921, dan oleh Dandy dan Taggart pada tahun 1942 sebagai suatu kelainan yang berhubungan dengan atresia kongenital saluran keluar foramina ventrikel IV. Istilah DWS pertamakali di kemukakan oleh Benda pada suatu serial autopsi di tahun 1954 untuk menggambarkan kondisi abnormal tersebut, serta mengajukan suatu teori baru tentang etiologi DWS (1).

\section{ANATOMI, EMBRIOLOGI DAN PATOFISIOLOGI}

Serebelum bertanggungjawab terhadap koordinasi gerak, khususnya gerakan halus yang disadari, kontrol gait dan postur tubuh, serta regulasi tonus otot. Serebelum juga memiliki beberapa peran dalam modulasi emosi serta beberapa aspek kognisi, meskipun mekanisme pasti mengenai fungsi ini masih belum jelas (3).

\section{Article History:}

Received: 9 Februari 2020; Accepted: 11 Februari 2020; Published: 1 Maret 2020

Cite As:

Damayanti R, Dafif MW, Kurniawan SN, Munir B, Afif Z. Dandy-Walker Variant (DWV) in 70 years old woman with disequilibrium and central vertigo : Case report. Journal of Pain, Vertigo and Headache; 2020.1:4-9. 
Berdasarkan struktur anatomi, studi komparasi serta hubungan jaras-jarasnya, serebelum dibagi ke dalam tiga bagian. Lobus flocculonodular, terletak di bagian inferior, yang secara filogenetis merupakan bagian tertua dari otak kecil (archicerebellum) dan relatif hampir sama pada semua hewan. Bagian ini terpisah dari bagian utama otak kecil atau korpus serebelli, oleh fisura posterolateral (2). Lobus anterior, atau paleocerebellum, terletak di bagian bagian rostral dari fisura utama.

Pada hewan yang lebih rendah, lobus anterior merupakan bagian terbesar dari otak kecil, tapi pada manusia bagian anterior relatif kecil, yang terdiri dari vermis anterosuperior dan korteks paravermian yang bersebelahan. (3) Lobus posterior, atau neocerebellum, yang terdiri dari divisi medial vermis dan divisi lateral yang besar. Bagian utama dari serebelum manusia ke dalam ini, yang merupakan subdivisi terbesar (3).

Subdivisi anatomi ini berkaitan secara kasar dengan pembagian fungsi-fungsi serebelum berdasarkan susunan koneksi serat aferen nya. Lobus flocculonodular menerima impuls proprioseptif khusus dari nukleus vestibular dan oleh karena itu disebut juga sebagai vestibulocerebellum; bagian ini memiliki fungsi utama yang berkaitan dengan keseimbangan. Vermis anterior dan sebagian dari vermis posterior disebut sebagai spinocerebellum, karena proyeksi jaras menuju bagian ini berasal sebagian besar dari proprioseptor-proprioseptor di otot dan tendon pada ekstremitas. Pengaruh utama spinocerebellum terutama pada pengaturan postur dan otot. Neocerebellum memiliki serat aferen yang berasal secara tidak langsung dari korteks serebral melalui nuklei pontine dan brachium pons, sehingga disebut juga sebagai pontoserebelum. Bagian ini terutama berhubungan dengan fungsi koordinasi gerakan terampil yang dimulai pada tingkat kortikal otak. Bagian-bagian tertentu dari belahan serebelum saat ini diduga juga terlibat sampai batas tertentu pada fungsi taktual, visual, auditori, dan bahkan fungsi visceral (3).

Perkembangan serebelum dimulai pada minggu kesembilan kehamilan ketika genesis hemisfer serebelum muncul dari celah rhombik. Setelah itu, hemisfer serebelum berfusi untuk membentuk vermis. Pleksus koroid ventrikel keempat dan foramen Magendie terbentuk sekitar minggu ke-10 kehamilan dari vesikel rhombik. Ventrikel keempat berkembang saat cairan serebrospinal (CSF) terakumulasi dalam ruang tersebut. Lobulus serebelar berkembang dari anterior ke arah posterior dan sepenuhnya terbentuk pada minggu 18. Serebelum berkembang lebih lambat dari hemisfer serebri dan oleh karena itu pada minggu 20 kehamilan tampak relatif lebih kecil terhadap ruang CSF fossa posterior, hak ini berpotensi menyebabkan overdiagnosis hipoplasia vermis pada saat dilakukan USG antenatal (1).

Pada analisis patologis yang dilakukan oleh Benda dari enam kasus, disimpulkan bahwa anomali perkembangan ini secara langsung berkaitan dengan tidak terjadinya regresi velum medula posterior yang tetap ada sebagai membran arakhnoid dan ektodermal yang tebal. Vermis serebelar tidak terbentuk. Pada akhirnya, terbentuk kista pada ujung kaudal ventrikel keempat, yang memisahkan hemisfer serebelar. Meskipun sering ditemukan, kegagalan perkembangan foramen Magendie tidak penting pada perkembangan DWS. Temuan radiografi khas yang mendukung DWS antara lain, agenesis vermis serebelar, dilatasi kistik ventrikel IV dan fossa posterior, dan elevasi lokasi sinus venaosus transversus dan pertemuannya (1).

Pada sebuah studi patologi postmortem pada pasien berusia 23 tahun dengan DWS, ditemukan adanya sel-sel Purkinje normal yang berselang-seling dengan sel abnormal yang menunjukan penurunan ukuran sel somatik, yang dominan berada di tonsil dan vermis serebelum, serta berkurangnya ketebalan sel dendritik, yang memiliki karakteristik hilangnya cabang sel dendritik dan spina. Di korteks serebral dan hippocampus, temuan yang paling menonjol adalah konfigurasi yang berliku-liku bagian apikal dendrit neuron piramidal, edema fokal akson dan dendrit, dan astrositosis reaktif. Pembuluh darah, kapiler otak dan korteks serebelar berkembang secara abnormal, tampak dilatasi fokal dan striktur. Semua temuan di atas mungkin tidak hanya terkait dengan perubahan perkembangan yang disebabkan oleh malformasi Dandy-Walker, tetapi juga karena tekanan intrakranial yang meningkat oleh hidrosefalus yang terjadi bersamaan. $^{5}$
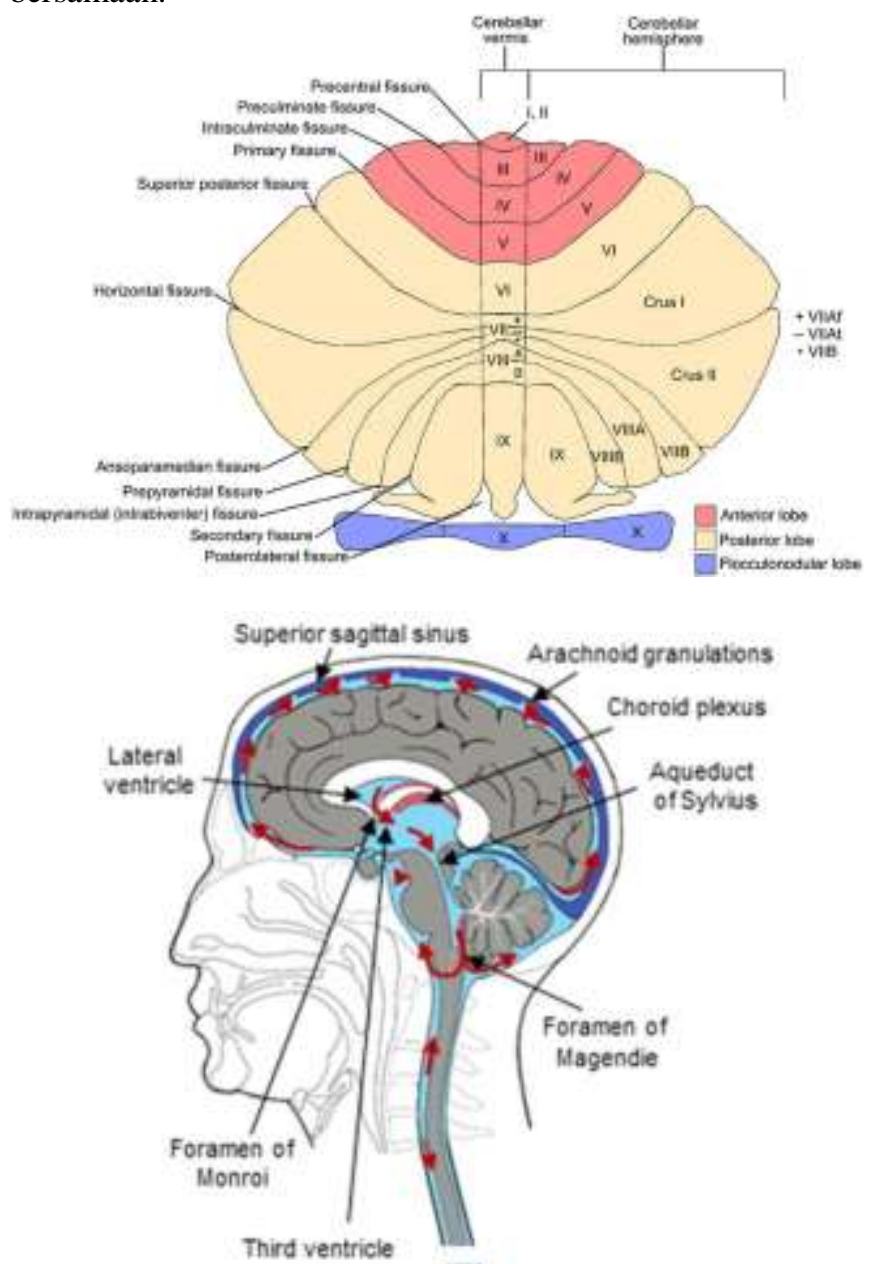

Gambar 1. A. Diagram serebelum, menampilkan ilustrasi fisurafisura utama, lobus, dan divisi filogenetik utama (3). B. Skema potongan sagital otak dan aliran cairan sereberospinal (4) 

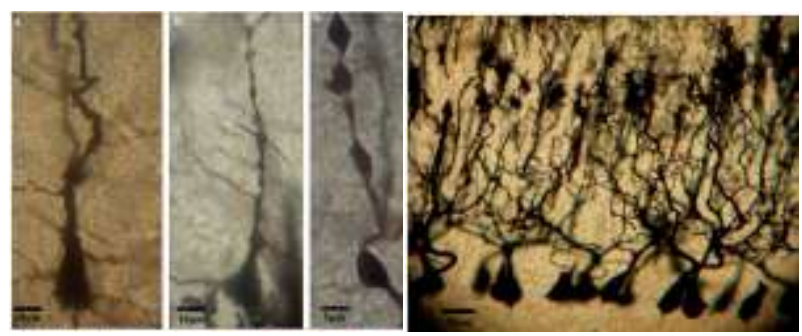

Gambar 2. Kelaina patologis pada DWS. Perubahan morfologi Golgi neuron di berbagai regio otak: a) struktur berliku-liku apikal dendrit pada neuron piramidal di hipokampus, b) dan c) dilatasi fokal dendrit pada neuron di lobus temporal, d) miskinnya penjuluran dendritik di sel Purkinje (5).

\section{EPIDEMIOLOGI}

Dandy Walker Syndrome dan tipe variannya merupakan kelainan kongenital yang dilaporkan memiliki prevalensi kejadian 1 dari 25.000 sampai 30.000 kelahiran dengan angka insidensi tertinggi terjadi pada usia kurang dari 1 tahun (1). Meskipun demikian, pasien mungkin baru terdiagnosis mengalami DWS/DWV pada usia remaja bahkan usia tua. Pasien tertua yang baru terdiagnosis mengalami DWV berusia 75 tahun. Dandy Walker Syndrome lebih sering ditemukan pasa wanita dengan perbandingan pria dan wanita $(1: 1,5)(6)$

Seperti telah dijelaskan sebelumnya, DWS/V dapat asimptomatik dan ditemukan secara tidak sengaja pada pemeriksaan neuroimaging. Villar dan kolega melaporkan sebuah kasus Dandy Walker pada wanita berusia 61 tahun yang mengalami keluhan sinkop tanpa disertai kelainan kognitif dan motorik sebelumnya. Pada hasil pemeriksaan imaging, pada wanita tersebut ditemukan kelainan lain yang menyertai DWV berupa agenesis arteri serebelli posterior inferior (7). Sebuah kasus DWV asimptomatik lain pada seorang wanita berusia 32 tahun, telah dilaporkan oleh Tadakamadla dan rekan pada saat pemeriksaan neuroimaging dan check up rutin pasien tersebut. Dari pemeriksaan klinis lebih jauh pada pasien tersebut didapatkan gait dan sensoris yang normal, namun dengan IQ yang rendah (55), hipertelorisme, dan makrosefali (6).

\section{KLASIFIKASI}

Untuk memperjelas terminologi dan klasifikasi, Dandy Walker Syndrome di klasifikasikan menurut Choutka dan Mangano dalam makalahnya sebagai berikut (1):

\section{Dandy Walker Syndrome (DWS)/ Dandy Walker} Malformation (DWM) klasik

Merupakan suatu malformasi kongenital yang ditandai dengan karakteristik khas yang terdiri oleh adanya hipoplasi vermis serebelum, dilatasi kistik ventrikel ke empat, dan pembesaran fossa posterior, baik disertai ataupun tanpa disertai hidrosefalus.

2. Dandy Walker Variant (DWV)

Merupakan suatu terminologi yang digunakan pertama kali oleh Harwood-Nash dan Fitz, untuk menggambarkan kondisi kelainan DWS yang lebih ringan dan tidak sepenuhnya sesuai dengan gambaran klasik DWS. Yang termasuk dalam kelainan DWV ini antara lain adanya defek pada vermis inferior serebelum dan adanya hubungan antara ventrikel IV dengan sisterna magna yang berukuran relatif normal.

3. Dandy Walker Compleks (DWC)

Terminologi ini digunakan untuk menggambarkan kelainan fossa posterior yang di kelompokan menjadi:

a. Mild (hanya terdapat mega sisterna magna saja)

b. Moderate ( jika terdapat hipoplasia ringan vermis serebelum, pembesaran ventrikel IV)

c. Severe ( jika terjadi agenesis vermis, dilatasi fossa posterior dan dilatasi ventrikel IV) (1).

\section{GEJALA KLINIS}

Gejala klinis yang menyertai DWS sangat bervariasi, umumnya gejala klinis yang terjadi tergantung pada kelainan anatomi yang mendasari, sertai usia saat manifestasi kelainan tersebut muncul $(1,2,8,9)$. Pada masa neonatus, pembesaran ukuran kepala (makrosefali), kelainan struktur kepala (serebro-fronto-fasial sindrome) yang mungkin disebabkan oleh karena hidrosefalus dan mega sisterna, merupakan gejala klinis utama yang tersering menyertai kelainan DWS $(3,10,12,15)$ mungkin hal ini diakibatkan masih belum tertutupnya sutura dan belum mengerasnya struktur tulang kepala pada usia tersebut.

Tabel 1. Gejala-gejala klinis yang meyertai Dandy Walker Syndrome dan Varian

\begin{tabular}{|c|c|c|c|}
\hline No & Klinis & $\begin{array}{c}\text { Usia saat } \\
\text { ditemukan }\end{array}$ & Keterangan \\
\hline 1 & Hidrosefalus & $\begin{array}{c}\text { bervariasi dari } \\
\text { intrauteri hingga } \\
\text { usia } 75 \text { tahun }\end{array}$ & $(1,3,6,8,10,11)$ \\
\hline 2 & $\begin{array}{l}\text { Agenesis corpus } \\
\text { callosum }\end{array}$ & Antenatal & $(1,3,10,12)$ \\
\hline 3 & $\begin{array}{l}\text { Melanositosis } \\
\text { neurokutaneus }\end{array}$ & Postnatal & (13) \\
\hline 4 & Hipoparatiroid & Postnatal & (14) \\
\hline 5 & $\begin{array}{c}\text { Makrosefalus, } \\
\text { makrokrania }\end{array}$ & $\begin{array}{c}\text { postnatal, anak- } \\
\text { anak }\end{array}$ & $(1,6,11,15)$ \\
\hline 6 & Kejang & Bervariasi & $(1,3,12)$ \\
\hline 7 & Lethargi & Bervariasi & $(1,3,12)$ \\
\hline 8 & $\begin{array}{c}\text { Hambatan } \\
\text { tumbuhkembang, } \\
\text { IQ yang rendah }\end{array}$ & $\begin{array}{c}\text { post natal, anak } \\
\text { anak }\end{array}$ & $(1,5,6,16)$ \\
\hline 9 & $\begin{array}{c}\text { Ataksia/disequilib } \\
\text { rium dan } \\
\text { nistagmus }\end{array}$ & $\begin{array}{l}\text { postnatal, anak- } \\
\text { anak, hingga } \\
\text { dewasa } \\
\end{array}$ & $(1,3,5,12,17)$ \\
\hline 10 & Sinkop & Dewasa & (7) \\
\hline 11 & $\begin{array}{c}\text { Trigeminal } \\
\text { neuralgia }\end{array}$ & Dewasa & (11) \\
\hline 12 & $\begin{array}{c}\text { Oksipital } \\
\text { ensefalokel }\end{array}$ & Postnatal & (11) \\
\hline 13 & Psikosis & $\begin{array}{c}\text { bervariasi dari } \\
\text { usia } 15 \text { tahun } \\
\text { hingga } 45 \text { tahun }\end{array}$ & (18) \\
\hline 14 & Skizofrenia & Dewasa & (9) \\
\hline
\end{tabular}

Pada DWS atau DWV yang terjadi pada usia yang lebih tua, gejala klinis menjadi lebih tidak khas, meliputi spektrum klinis yang sangat luas mulai dari pembesaran ukuran kepala dengan lekukan suboksipital yang menonjol, nyeri kepala, ataksia, trigeminal neuralgia, kejang, penurunan IQ, psikosis, skizofrenia, hingga tanpa adanya gejala dan hanya secara 
kebetulan ditemukan pada prosedur neuroimaging $(2,8,13,15,19)$.

\section{DIAGNOSIS}

Diagnosis ditegakan berdasarkan klinis dan di pastikan dengan gambaran radiologis sesuai klasifikasi penyakit.

\section{Diagnosis Banding}

Diagnosis banding DWS dan DWV di rangkup pada tabel 2.

\section{TERAPI}

Tujuan utama terapi pada kasus DWS adalah untuk mengontrol hidrosefalus dan mengatasi kista di fossa posterior. Beberapa metode telah diajukan, namun metode metode tersebut masih kontroversial(10). Dalam dua dekade terakhir, manajemen bedah dengan melakukan kraniotomi fossa posterior berserta eksisi membran kista, beralih kepada metode shunt. Tindakan shunt ini menurunkan kematian dan kecacatan cukup bermakna. Meskipun demikian, tindakan shunt pada DWS tampaknya memiliki komplikasi yang lebih sering dibandingkan pada kasus-kasus hidrosefalus yang diakibatkan oleh sebab lain. Tindakan neuroendoskopi dapat digunkan sebagai alternatif tindakan yang cukup bermanfaat pada beberapa kasus.

Tabel 2. Diagnosis banding Dandy Walker Syndrome /Varian

\begin{tabular}{ccc}
\hline No. & $\begin{array}{c}\text { Diagnosis } \\
\text { banding }\end{array}$ & Keterangan \\
\hline 1 & $\begin{array}{c}\text { Kista arachnoid } \\
\text { medial }\end{array}$ & $\begin{array}{c}\text { Dibedakan dari DWS dengan } \\
\text { mengidentifiasi jaringan serebelum } \\
\text { atau adanya septum antara kista dan } \\
\text { ventrikel IV(20) }\end{array}$ \\
\hline 2 & $\begin{array}{c}\text { Mega sisterna } \\
\text { magna }\end{array}$ & Sama dengan atas(20) \\
\hline 3 & $\begin{array}{c}\text { Arnold-chiari } \\
\text { malformation }\end{array}$ & $\begin{array}{c}\text { Adanya ekstensi tonsil serebelum ke } \\
\text { dalam kanalis spinalis servikalis, } \\
\text { dan bagian inferior ventrikel IV, } \\
\text { sering bersamaan dengan } \\
\text { siringomyelia(3) }\end{array}$ \\
\hline
\end{tabular}

\section{KASUS}

Seorang wanita 70 tahun datang berobat ke poliklinik dengan keluhan utama jalan geloyoran. Pasien mengeluh mengalami jalan geloyoran sejak kurang lebih 9 bulan sebelum opname, yang dirasakan memberat secara perlahan-lahan, namun sejak 6 bulan terakhir dirasakan cenderung menetap. Jalan geloyoran dikatakan pasien semakin memberat jika digunakan beraktifitas yang lama. Tidak ada rasa lemah setengah badan, tebal setengah badan, pelo, merot, nyeri kepala, pandangan dobel, mual, muntah, ngompol, ngebrok, gangguan penciuman dan gangguan pendengaran. Namun demikian, pasien masih dapat melakukan aktifitas sehari harinya secara mandiri.

Pasien juga mengaku mengalami pusing berputar yang dirasaakan sejak kurang lebih 3 bulan sebelum datang ke poli saraf. Pusing berputar dirasakan sepanjang hari dengan intensitas yang ringan, tanpa disertai mual dan muntah saat serangan, tidak dipengaruhi oleh perubahan posisi, tanpa disertai suara berdenging dan tidak disertai penurunan pendengaran selama pusing berputar berlangsung.

Riwayat nyeri kepala kronis disangkal, riwayat stroke sebelumnya disangkal,riwayat trauma kepala disangkal, riwayat batuk lama dan batuk darah disangkal, keringat malam(-), penurunan berat badan(-), gemetaran(-), sering lupa terhadap sesuatu hal(-). Sakit seperti ini sebelumnya(-). Nyeri leher(+) pasien didiagnosis mengalami spondilosis lumbalis sejak 2 tahun yang lalu dan rutin berobat, riwayat trauma kepala sebelumnya(-), riwayat stroke(-), riwayat tumor aau keganasan(-), DM (+) sejak 10 tahun yang lalu, rutin berobat dan terkontrol, kolesterol(+), sejak 5 tahun yang lalu, rutin berobat, Hipertensi (-).

Pada pemeriksaan fisik didapatkan GSC 456, tekanan darah 120/70mmHg, nadi 90x/menit reguler, dengan suhu aksila $36,5^{\circ} \mathrm{C}$. Pemeriksaan kepala, leher, thoraks, abdomen, dan ekstremitas dalam batas normal. Dari pemeriksaan neurologis didapatkan didapatkan nistagmus sentral, nervus kranialis lain dalam batas normal. Pemeriksaan motorik, sensoris dan otonom dalam batas normal. Pemeriksaan romberg test, tandem walking, disdiadokokinesia, dan dismetria abnormal. Hasil MMSE pasien dalam batas normal (skor:26).

Pada pemeriksan laboratorium didapatkan peningkatan nilai glukosa 2 jam post-prandial, dan HbA1C sementara hasil yang lain dalam batas normal (tabel 3).

Tabel 3. Hasil pemeriksaan laboratorium

\begin{tabular}{|c|c|c|}
\hline Pemeriksaan & Nilai & Nilai normal \\
\hline $\begin{array}{l}\text { Hemoglobin } \\
(\mathrm{HGB})\end{array}$ & $13,70 \mathrm{mg} / \mathrm{dl}$ & $11,4-15,1$ \\
\hline Eritrosit (RBC) & 4,30 juta & $4,0-5,0$ juta \\
\hline Leukosit (WBC) & $8.100 / \mu \mathrm{L}$ & $4,7-11,3$ \\
\hline Hematokrit & $36,1 \%$ & $38-42$ \\
\hline Trombosit (PLT) & $312.000 / \mu \mathrm{L}$ & $142-424$ \\
\hline \multicolumn{3}{|l|}{ Hitung Jenis: } \\
\hline Eosinofil & $1 \%$ & $0-4$ \\
\hline Basofil & $0,1 \%$ & $0-1$ \\
\hline Neutrofil & $60,5 \%$ & $51-67$ \\
\hline Limfosit & $31,9 \%$ & $25-33$ \\
\hline Monosit & $3,7 \%$ & $2-5$ \\
\hline SGOT (AST) & $22 \mathrm{U} / \mathrm{L}$ & $0-32$ \\
\hline SGPT (ALT) & $32 \mathrm{U} / \mathrm{L}$ & $0-33$ \\
\hline $\begin{array}{c}\text { Gula darah } \\
\text { Sewaktu }\end{array}$ & $151 \mathrm{mg} / \mathrm{dL}$ & $<200$ \\
\hline Gula darah puasa & $108 \mathrm{mg} / \mathrm{dl}$ & $60-100$ \\
\hline $\begin{array}{c}\text { Gula darah } 2 \text { jam } \\
\text { PP }\end{array}$ & $150 \mathrm{mg} / \mathrm{dl}$ & $<130$ \\
\hline HbA1c & $6,70 \%$ & $<5,7$ \\
\hline Ureum & $31,2 \mathrm{mg} / \mathrm{dL}$ & $16,6-48,5$ \\
\hline Kreatinin & $0,57 \mathrm{mg} / \mathrm{dL}$ & $<1,2$ \\
\hline Albumin & $3,62 \mathrm{~g} / \mathrm{dL}$ & $3,5-5,5$ \\
\hline Natrium $(\mathrm{Na})$ & $136 \mathrm{mmol} / \mathrm{L}$ & $136-145$ \\
\hline Kalium (K) & $3,91 \mathrm{mmol} / \mathrm{L}$ & $3,5-5,0$ \\
\hline Klorida $(\mathrm{Cl})$ & $105 \mathrm{mmol} / \mathrm{L}$ & $98-106$ \\
\hline T3 Total & $0,55 \mathrm{Ng} / \mathrm{mL}$ & $0,8-2,0$ \\
\hline $\mathrm{T} 4$ & $1,43 \mathrm{Ng} / \mathrm{mL}$ & $0,93-1,7$ \\
\hline Free TSH & $2,35 \mu \mathrm{IU} / \mathrm{mL}$ & $0,270-4,20$ \\
\hline Asam urat & $3,6 \mathrm{mg} / \mathrm{dl}$ & $6-10 \mathrm{mg} / \mathrm{dl}$ \\
\hline
\end{tabular}

Dari hasil pemeriksaan MRI kepala didapatkan lesi isointens pada T1W1, hiperintens T2W1/FLAIR di sentrum semiovale kiri disertai periventrikular caps. Sulcii, fisura sylvii melebar dan gyri prominen, differensiasi white dan gray matter baik. 
Pada infratentorial: mesencephalon, pons dan sudut serebellopontin baik. Tampak pelebaran sisterna magna yang berhubungan dengan kanalis spinalis dengan atropi serebeli sesuai dengan gambaran Dandy Walker Variant disertai atrofi srerebri dan serebelli dengan degenerasi fazekas grade I.

\section{PEMBAHASAN}

Penegakan diagnosis Dandy Walker Variant pada kasus ini, seorang wanita usia 70 tahun dengan keluhan utama berupa kronik non progresif disequilibrium dengan vertigo sentral, didasarkan pada anamnesis, pemeriksaan fisik dan rangkaian pemeriksaan penunjang. Diagnosis banding pada pasien ini adalah suatu proses degeneratif pada otak yang menyebabkan penurunan fungsi otak karena suatu atropi otak yang umumnya terjadi pada pasien lanjut usia. Setelah dilakukan pemeriksaan MRI kepala ternyata ditemukan suatu kelainan struktural pada serebelum berupa Dandy Waker Variant disertai adanya atropi serebri dan serebelum.

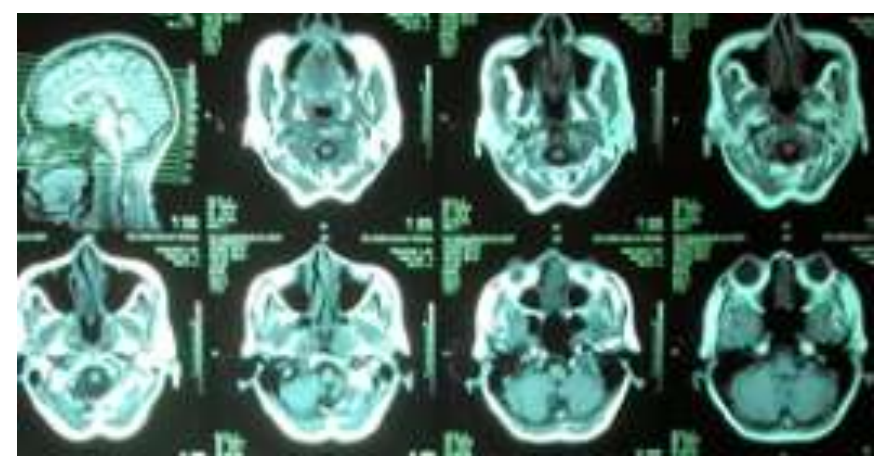

(a)

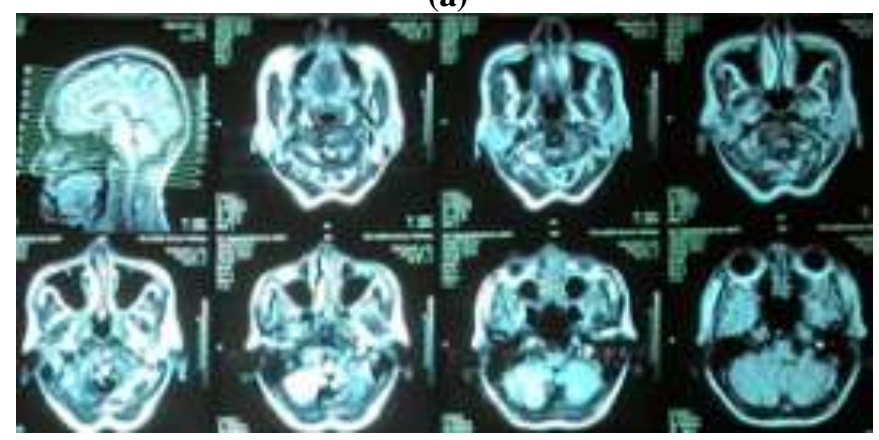

(b)

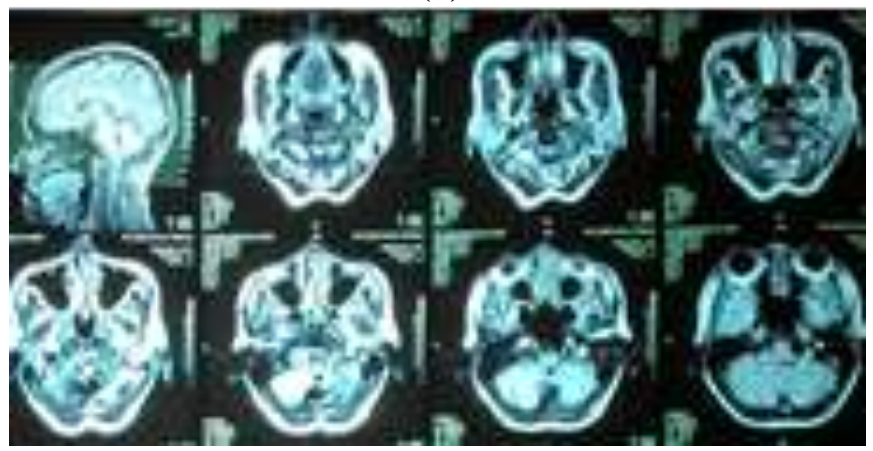

(c)

Gambar 2. a,b,c. sekuens T1W1, T2W1, FLAIR MRI kepala pasien menunjukan gambaran DWV.

Dandy Walker Sindrome dan tipe variannya merupakan kelainan kongenital yang dilaporkan memiliki prevalensi kejadian 1 dari 25.000 sampai 30.000 kelahiran dengan angka insidensi tertinggi terjadi pada usia kurang dari 1 tahun (1).
Meskipun demikian, pada kasus yang sangat jarang terjadi, pasien mungkin baru terdiagnosis mengalami DWV pada usia tua. Pasien tertua yang dilaporkan pertama kali terdiagnosis DWV berusia 75 tahun. Dandy Walker Syndrome lebih sering ditemukan pasa wanita dengan perbandingan pria dan wanita $(1: 1,5)$. Pada kasus ini, pasien pertama kali terdiagnosis menderita kelaianan DWV pada usia 70 tahun setelah sebelumnya mulai mengeluhkan gejala gangguan disequilibrium dan vertigo sentral sejak 9 bulan sebelumnya.

Dandy Walker Varian merupakan suatu terminologi yang digunakan pertama kali oleh Harwood-Nash dan Fitz, untuk menggambarkan kondisi kelainan DWS yang lebih ringan dan tidak sepenuhnya sesuai dengan gambaran klasik DWS. Yang termasuk dalam kelainan DWV ini antara lain adanya defek pada vermis inferior serebelum dan adanya hubungan antara ventrikel IV dengan sisterna magna yang berukuran relatif normal ${ }^{1}$. Kelainan pada serebelum yang diakibatkan oleh DWV dapat menyebabkan beragai macam manifestasi klinis (1). Disequilibrium dan vertigo sentral merupakan salah satu gejala yang diduga berkaitan erat dengan kelainan ini $(1,3,5,12,17)$. Serebelum bertanggungjawab terhadap koordinasi gerak, khususnya gerakan halus yang disadari, kontrol gait dan postur tubuh, dan regulasi tonus otot. Lobus flocculonodular menerima impuls proprioseptif khusus dari nukleus vestibular dan oleh karena itu disebut juga sebagai vestibulocerebellum; bagian ini memiliki fungsi utama yang berkaitan dengan keseimbangan. Vermis anterior dan sebagian dari vermis posterior disebut sebagai spinocerebellum, karena proyeksi jaras menuju bagian ini berasal sebagian besar dari proprioseptor-proprioseptor di otot dan tendon pada ekstremitas. Pengaruh utama spinocerebellum terutama pada pengaturan postur dan otot. Neocerebellum memiliki serat aferen yang berasal secara tidak langsung dari korteks serebral melalui nuklei pontine dan brachium pons, sehingga disebut juga sebagai pontoserebelum. Bagian ini terutama berhubungan dengan fungsi koordinasi gerakan terampil yang dimulai pada tingkat kortikal otak (3). Kelainan-kelaianan yang menggangu fungsi serebelum tersebutlah yang diduga menyebabkan munculnya manifestasi klinis disequilibrium dan vertigo sentral pada kasus ini.

Tujuan utama terapi pada kasus DWS adalah untuk mengontrol hidrosefalus dan mengatasi kista di fossa posterior. Beberapa metode telah diajukan, namun metodemetode tersebut masih kontroversial (10). Dalam dua dekade terakhir, manajemen bedah dengan melakukan kraniotomi fossa posterior berserta eksisi membran kista, beralih kepada metode shunt. Tindakan shunt ini menurunkan kematian dan kecacatan cukup bermakna. Meskipun demikian, tindakan shunt pada DWS tampaknya memiliki komplikasi yang lebih sering dibandingkan pada kasus-kasus hidrosefalus yang diakibatkan oleh sebab lain. Tindakan neuroendoskopi dapat digunkan sebagai alternatif tindakan yang cukup bermanfaat pada beberapa kasus.

Pada pasien ini, tindakan operatif tidak dilakukan karena pada pasien tidak ditemuakan adanya hidrosefalus ataupun tanda peningkatan tekanan intrakranial sebagai indikasi operasi, sehingga terapi yang diberikan berupa terapi simptomatis dengan pemberian medikamentosa yaitu metformin 3x500 mg untuk mengontrol kadar gula darah pasien, dan betahistine mesylate 3x6mg tablet. Betahistin ( $N$ - 
alpha-methyl-2-pyridylethyl-amine merupakan analog histamin dan memiliki efek farmakologis yang mirip dengan histamin. Betahistine merupakan suatu agonis reseptor $\mathrm{H} 1$ lemah, antagonis reseptor $\mathrm{H} 3$ yang poten, dan aktifitas terhadap reseptor $\mathrm{H} 2$ yang dapat di abaikan (21). Sebagai antagonis reseptor $\mathrm{H} 3$ yang poten, betahistine memblok supresi pelepasan sinaptik histamin dan transmiter-transmiter lain yang diinduksi oleh histamin eksogen melalui autoreseptor $\mathrm{H} 3$, efek ini akan meningkatkan aliran darah pada sistem vestibulokoklear yang berefek protektif. Pada mekanisme sentral, betahistin meningkatkan sintesis histamin pada nukleus tuberomamilaris dan meningkatkan pelepasan histamin pada nukleus vestibular melalui antagonime autoreseptor H3. Mekanisme ini dapat mendorong dan memfasilitasi kompensasi vestibular (21).

Penyebab utama kematian pada kasus DWV adalah hidrosefalus yang tak terkontrol, infeksi, dan komplikasi dari tindakan shunt. Data-data penelitian mengenai prognosis DWV pada usia lanjut yang telah terdokumentasi masih sangat sedikit $(8,11,15)$. Namun, pada pasien ini, angka mortalitas mungkin kecil karena secara klinis, gejala yang dialami oleh pasien tidak progresif dan cenderung menetap serta tidak adanya hidrosefalus yang merupakan salah satu kegawatan pada kasus-kasus DWV.

Edukasi dan penjelasan yang baik kepada pasien telah diberikan sehingga pasien dapat beradaptasi dengan kondisinya serta dapat mendeteksi secara dini jika terjadi tanda-tanda kegawatan akibat hidrosefalus yang mungkin dapat terjadi dimasa datang. Laporan kasus ini diharapkan dapat digunakan sebagai salah satu data penting yang dapat dirujuk sebagai referansi pada kasus-kasus DWV pada usia lanjut yang masih sangat sedikit terdokumentasi.

\section{DAFTAR PUSTAKA}

1. Choutka O, Mangano FT. Dandy-Walker Syndrome [Internet]. Youmans Neurological Surgery. Elsevier; 2011. p. 1906-10. Available from: http://dx.doi.org/10.1016/b978-1-4160-5316-3.00180-5

2. Spennato P, Mirone G, Nastro A, Buonocore MC, Ruggiero C, Trischitta V, et al. Hydrocephalus in DandyWalker malformation. Child's Nerv Syst [Internet]. 2011;27(10):1665-81. Available from: http://dx.doi.org/10.1007/s00381-011-1544-4

3. Ropper A., Samuel M., J.P K. Principles of Neurology. 10th Editi. Adams and Victor's Principles of neurology. New York: Mc Graw Hill; 2014.

4. Orešković D, Radoš M, Klarica M. Role of choroid plexus in cerebrospinal fluid hydrodynamics. Vol. 354, Neuroscience. Elsevier Ltd; 2017. p. 69-87.

5. Mytilinaios DG, Tsamis KI, Njau SN, Polyzoides K, Baloyannis SJ. Neuropathological findings in Dandy Walker Variant. Dev Neurorehabil [Internet]. 2010;13(1):64-7. Available from: http://dx.doi.org/10.3109/17518420903236254

6. Tadakamadla J, Kumar S, Mamatha GP. Dandy-Walker malformation: An incidental finding. Indian J Hum Genet [Internet]. 2010 Jan;16(1):33-5. Available from: https://www.ncbi.nlm.nih.gov/pubmed/20838490

7. Domínguez RO, González SE, Saenz Valiente A, Pinkala E. Agenesis of posterior inferior cerebellar arteries in an asymptomatic adult with Dandy-Walker malformation. Neurol (English Ed [Internet]. 2012;27(7):445-6. Available from: http://dx.doi.org/10.1016/j.nrleng.2012.08.002

8. Notaridis G, Ebbing K, Giannakopoulos P, Bouras C, Kovari E. Neuropathological analysis of an asymptomatic adult case with Dandy-Walker variant. Neuropathol Appl Neurobiol [Internet]. 2006;32(3):344-50. Available from: http://dx.doi.org/10.1111/j.1365-2990.2006.00719.x

9. Kvitvik Aune I, Bugge E. Schizophrenia in a Young Man with Dandy-Walker Variant. Biol Psychiatry [Internet]. 2014;75(5):e9-10. Available from: http://dx.doi.org/10.1016/j.biopsych.2013.05.034

10. Spennato P, Mirone G, Nastro A, Buonocore MC, Ruggiero C, Trischitta V, et al. Hydrocephalus in DandyWalker malformation. Child's Nerv Syst. 2011;27(10):1665-81.

11. Jha VC, Kumar R, Srivastav AK, Mehrotra A, Sahu RN. A case series of 12 patients with incidental asymptomatic Dandy-Walker syndrome and management. Child's Nerv Syst. 2012;28(6):861-7.

12. Daroff R., Fenichel GM, Jankovic J. Bradley's Neurology in Clinical Practice. 10th Editi. USA: Elsevier Ltd; 2012.

13. De Cock J, Snauwaert J, Van Rompaey W, Morren M-A, Demaerel P. A Newborn With Neurocutaneous Melanocytosis and Dandy-Walker Malformation. Pediatr Neurol [Internet]. 2014;50(3):276-8. Available from: http://dx.doi.org/10.1016/j.pediatrneurol.2013.04.006

14. Coban D, Akin MA, Kurtoglu S, Öktem S, Yikilmaz A. Dandy-Walker Malformation: A Rare Association With Hypoparathyroidism. Pediatr Neurol [Internet]. 2010;43(6):439-41. Available from: http://dx.doi.org/10.1016/j.pediatrneurol.2010.06.006

15. Tonni G, Azzoni D, Ambrosetti F, De Felice C, Ventura A. Cerebro-fronto-facial syndrome (Dandy-Walker variant and frontofacial dysmorphisms): Report of the first case identified by increased nuchal translucency beyond 13+6 weeks. Congenit Anom (Kyoto) [Internet]. 2007;47(2):68-71. Available from: http://dx.doi.org/10.1111/j.1741-4520.2007.00146.x

16. Boddaert N, Klein O, Ferguson N, Sonigo P, Parisot D, Hertz-Pannier L, et al. Intellectual prognosis of the Dandy-Walker malformation in children: the importance of vermian lobulation. Neuroradiology [Internet]. 2003;45(5):320-4. Available from: http://dx.doi.org/10.1007/s00234-003-0980-6

17. Bonthius DJ. Ataxia and the Cerebellum. Semin Pediatr Neurol [Internet]. 2011;18(2):69-71. Available from: http://dx.doi.org/10.1016/j.spen.2011.05.001

18. Gan Z, Diao F, Han Z, Li K, Zheng L, Guan N, et al. Psychosis and Dandy-Walker complex: Report of four cases. Gen Hosp Psychiatry. 2012;34(1):102.e7-102.e11.

19. Lacour M, Sterkers O. Histamine and Betahistine in the Treatment of Vertigo. CNS Drugs [Internet]. 2001;15(11):853-70. Available from: http://dx.doi.org/10.2165/00023210-200115110-00004

20. Lindsay W., Bone I, Callander R. Neurology and Neurosurgery Illustrated. 4th Editio. London: Livingstone; 2004.

21. Lacour M, Sterkers O. Histamine and betahistine in the treatment of vertigo: elucidation of mechanisms of action. CNS Drugs. 2001;15(11):853-70. 